\title{
DIASPORA AND CONFLICT: LOCALITY, LONG-DISTANCE NATIONALISM, AND DELOCALISATION OF CONFLICT DYNAMICS JOLLE DEMMERS
}

\begin{abstract}
Intra-state violent conflicts are no longer fought solely in the actual war territories. Increasingly, conflicts seem to become dispersed and delocalised. Stories about American Jewish groups supporting right-wing

extremism in Israel, German Croats speeding the violent collapse of Yugoslavia, and the Tamil Tigers in London, Kurds in the Netherlands, Filipinos, Khmer, and Vietnamese in California are not new to us. Within the field of Conflict Studies, however, the process of the

"deterritorialisation" of conflict is left surprisingly unexplored. In this paper we will examine the political mobilisation of diaspora communities and their role in

intra-state conflicts. How and why are diaspora communities involved in intra-state conflicts in their erstwhile homelands? What activities do they undertake? How are they organised? What strategies

do they use? And, eventually, how do they affect

contemporary conflicts? By examining these issues we aim to understand more about the dialectics between locality and conflict, the production of (long-distance) nationalism, and the relationship between virtual and spatial communities.
\end{abstract} Jolle Demmers lectures and conducts research at the Centre for Conflict Studies, Utrecht University, e-mail: Jolle.Demmers@let.uu.nl. 


\section{New Patterns of Conflict, Mobility and Boundaries}

Intra-state violent conflicts are no longer fought solely in the actual war territories: in the villages of Ambon, the jungle of Sri Lanka, or the occupied territories of Israel. Increasingly, conflicts seem to become dispersed and delocalised. Stories about American Jewish groups supporting right-wing extremism in Israel, German Croats speeding the violent collapse of Yugoslavia, and the Tamil Tigers in London, Kurds in the Netherlands, Filipinos, Khmer, and Kosovar Albanians in Western Europe and the U.S. are not new to us. Within the field of Conflict Studies, however, the process of the "deterritorialisation" of conflict is left surprisingly unexplored. Many questions about the political mobilisation of diaspora communities and their role in intra-state conflicts remain unanswered. How and why are diaspora communities involved in intra-state conflicts in their erstwhile homelands? What activities do they undertake? How are they organised? What strategies to they use? And, eventually, how do they affect contemporary conflicts? In this paper I will explore the deterritorialisation and delocalisation of contemporary conflict. By looking at ideas on locality, long-distance nationalism, and conflict dynamics I aim to identify units of analysis to understand the role of diaspora in contemporary conflict.

The nature of diasporic politics is manifold and highly case-specific. Kaldor (1996), for instance, points at the presence of both cosmopolitan anti-nationalist and reactionary ethno-nationalists within diasporas. Others (such as Homi Bhabha 1994, Appadurai 1995) see room for hybrid, diasporic "third space" standpoints. The impact of diaspora activities on contemporary conflicts is also highly miscellaneous. In some cases diasporic connections seem to feed and prolong the conflict. In other cases diasporic voices and initiatives can plead for reconciliation and demobilisation. Examples of diasporas acting as a strategic force in regional conflicts can be readily discerned. The sudden upsurge in strength of the Kosovo Liberation Army (KLA) during the summer of 1998 may have been at least partially due to fundraising efforts by the Albanian diaspora in the West. The Croatian diaspora was quite effective in helping swing the international community behind the Croats in their conflict with the Croatian Serbs in the mid-1990s. Armenian migrants in the U.S. have been working hard in the past years to compel the U.S. government to halt both its diplomatic overtures to the government of Azerbaijani and its efforts to help U.S. oil companies secure exploitation and drilling contracts in that petroleum rich Caspian state. The object of these moves is to weaken the longterm potential of the future Azerbaijani military threat to landlocked, resourcepoor Armenia. Finally, the Tamil diaspora in Canada and Western Europe has been active in funnelling financial support to the Tamil insurgents fighting the Sinhalese government forces in Sri Lanka.

Diasporas have existed in one form or another since ancient times. There are, however, reasons to believe that the political weight of diaspora communities has increased importantly throughout the late twentieth century, and that they often play a crucial role in contemporary conflicts. These reasons are (1) the rise of a new pattern of conflict; (2) the rapid rise of war refugees; (3) the increased speed of communication and mobility; and (4) the increased production of cultural and political boundaries. 
Throughout the late twentieth century a new pattern of conflict has evolved in which identity groups - racial, religious, ethnic, cultural and others - have become central. One of the first scholars to recognise this was Edward Azar. He argued for a radical revision of Clausewitzean ideas by claiming that it was the identity group - however defined - and not the nation-state that was at the core of most contemporary conflicts. At the end of the twentieth century, with the collapse of Yugoslavia and civil wars in the Caucasus, Indonesia and Africa, the idea that a "new pattern of conflict" had evolved became widespread. There is debate about whether this "new pattern" should be dated back to 1945 (and include the decolonisation wars of the 1950s and 1960s, and the post-colonial civil wars of the 1970s and 1980s) or that it only began with the ending of the Cold War in 1989. I will not discuss these large questions here. The phenomenon that most wars in the late twentieth century are within states, and that they are often about the role and status of nations and communities within these states is of concern to this research (see Wallensteen and Sollenberg 1997; Holsti 1996). These intra-state wars differ substantially from the European wars in the era of the dynastic state or from the "total wars" of the first half of the twentieth century (Maill et al 1998, 69). Kaldor and Vashee, for instance, characterise the "new wars" in terms of: political goals (no longer the foreign policy interests of states, but the consolidation of new forms of power based on ethnic homogeneity); ideologies (no longer universal principles such as democracy, fascism or socialism, but tribalist and communalist identity politics); forms of mobilisation (no longer conscription or appeals to patriotism, but fear, corruption, religion, magic and the media); external support (no longer superpowers or ex-colonial powers, but diaspora, foreign mercenaries, criminal mafia, regional powers); mode of warfare (no longer formal and organised campaigns with demarcated front-lines, bases and weapons, but fragmented, dispersed, involving paramilitary and criminal groups, child soldiers, light weapons, and the use of atrocity, famine, rape and siege); and the war economy (no longer funded by taxation and generated by state mobilisation, but sustained by outside emergency assistance and the parallel economy including unofficial export of timber and precious metals, drug-trafficking, criminal rackets, plunder; Kaldor and Vashee 1997, 7-19, Miall et al 1998, 69). In sum, new patterns of conflict have evolved which are distinct from traditional inter-state disputes over foreign policy, security, economic resources, or East-West rivalry and revolve around questions of status of identity groups within states.

What role do diaspora communities play in this new type of conflict? Since the nature of external support for contemporary conflict has become increasingly transnational diaspora communities have become the obvious group to mobilise external support. Since identity groups in conflict often lack formal international representation such as membership of the United Nations and a diplomatic corps, they largely depend upon their dispersed members for (the mobilisation of) external support.

A second, very straightforward, reason to presuppose the increasing importance of diaspora communities to contemporary conflicts is the rapid rise of war refugees. Since most contemporary conflicts are civil conflicts within states, the share of civilian casualties is very high. In the 1990s, over $90 \%$ of war-related deaths were civilians, killed in their own homes and communities (Miall et al 1998, 130). 
These vicious internal conflicts generate great numbers of refugees, who often leave the country at the same time. In sum, the new pattern of conflict rapidly produces diaspora.

Thirdly, because of the speed of communications and high mobility of people diaspora are increasingly capable of forging and sustaining social relations that link their societies of origin and settlement. Practically, this means that diaspora communities can easily participate in conflicts in their homelands and "live their politics long-distance" (Anderson 1992, 12). As Basch et al $(1994,34)$ already did note, by living their lives across borders diaspora find themselves confronted with and engaged in the nation-building processes of two or more nation-states. Their identities and practices are likely to be configured by hegemonic categories, such as race and ethnicity that are deeply embedded in the nation-building processes of these nation-states. In addition, diaspora communities are affected by how "their" conflict is viewed and treated within these various fields. In return, diasporas will be inclined to influence the various fields and contexts that they are engaged in. An example of this complex interrelatedness are the repeated efforts of Moluccan groups in The Netherlands to pressure the Dutch government to use its membership of the UN to call for humanitarian intervention in Indonesia. Another example includes the call on the Serbian diaspora by Serbian Deputy Premier Vojislav Sešelj to strike back "wherever they lived" in response to the NATO bombing campaign in March 1999.

A forth reason why diaspora are likely to continue to focus on their erstwhile homeland is that it has become increasingly hard to settle in "host" countries. Koser and Lutz (1998) argue that "the new racist nationalism which is gathering force in contemporary Europe is centrally concerned with notions of defending home, space and territory against 'the other,' a category which has come to include immigrants, asylum seekers, and ethnic minorities." Due to the increased production of cultural and political boundaries in countries of the Western world, contemporary diaspora have found full incorporation in the countries in the West within which they resettle either not possible or not desirable. Since new diaspora do not want to stake everything on an increasingly risky future in a single nation, they maintain close relationships with their ancestral homelands.

Until recently, conflict studies have focussed primarily on the relationship between identity groups and nation-states. As pointed out here, however, it is no longer possible to understand intra-state conflicts in terms of these units of analysis alone. Now with diaspora communities and international organisations playing important roles in nationalist struggles throughout the world, intra-state conflict must be approached from a more global perspective (see Danforth 1995, 79). Through the emergence of "virtual neighbourhoods" (Appadurai 1995) and "transnational national communities" (Danforth 1995) diaspora communities have become tied to political struggles at home.

In his introduction to the new journal Diaspora Tötölian (1991) loosely mixes the term diaspora with transnational community by stating that "Diaspora are the exemplary communities of the transnational moment." Further, he adds: "The term that once described Jewish, Greek, and Armenian dispersion now shares meanings with a larger semantic domain that includes words like immigrant, expatriate, refugee, guest-worker, exile community, overseas community, ethnic community" 
(Tötölian 1991, 4-5). Others prefer to distinguish diaspora from transnationalism. Whereas transnationalism is defined as a "process by which immigrants forge and sustain multi-stranded social relations that link together their societies of origin and settlement" (Basch et al 1994, 34), diasporas are at times defined as presupposing a separation more like exile (Clifford 1994, 304). In addition, whereas transnationalism generally presupposes the construction of social fields that link together communities in two nation-states, diaspora are often seen as more globally dispersed. Diaspora maintain a "triadic relationship" between (a) globally dispersed yet collectively self-identified ethnic groups; (b) the territorial states and contexts where such groups reside, and (3) the homeland states and contexts where they or their forbears came from (Vertovec 1999). Safran (1991, 83-84) uses a rather strict definition of diasporas, defining them as expatriate minority communities (1) that are dispersed from an original "centre" to at least two "peripheral" places; (2) that maintain a memory, vision, or myth about their original homeland; (3) that believe they are not-and perhaps cannot be-fully accepted by their host country; (4) that see the ancestral home as a place of eventual return, when the time is right; (5) that are committed to the maintenance or restoration of this homeland; and (6) of which the group's consciousness and solidarity are importantly defined by this continuing relation with the homeland. Whereas Tötölian's definition lacks precision Safran's checklist is perhaps too strict. I agree with Clifford $(1994,308)$ that we should be wary of constructing our working definition of a term like diaspora by recourse to an "ideal-type," with the consequence that groups become identified as "more" or "less" diasporic. I will therefore follow Clifford and use the term diaspora as a signifier, "not simply of translocality and movement, but of political struggles to define the local, as distinctive community, in historical contexts of displacement" (Clifford 1994, 308). We will look into this more deeply below.

\section{Diaspora and Conflict: Theoretical Frameworks}

In the contemporary world, group identities are no longer spatially or territorially bounded. People support, produce or cling to territorially based identities even though they do not actually live in the territory. Diaspora can actively be involved in violent conflicts at the other end of the world through electronic means, and influence these conflicts by sending money, arms, and opinions. How can we conceptualise these processes of deterritorialisation and delocalisation of conflict? First, we will look into the applicability of ideas on locality and (longdistance) nationalism. Second, we will pay attention to the delocalisation of conflict dynamics.

\section{The Production of Locality}

In a recent essay Appadurai (1995) analyses the transformation of the production of locality in a "dramatically delocalised world." Locality is seen as a property of social life and a structure of feeling: as a "complex phenomenological quality, constituted by a series of links between the sense of social immediacy, the technologies of interactivity and the relativity of contexts" (Appadurai 1995, 204). Locality is primarily relational and contextual rather than scalar or spatial. Appadurai uses the term "neighbourhood" to refer to the actually existing social forms in which locality, as a dimension or value, is variably realised. Neighbourhoods are situated 
communities characterised by their actuality and their potential for social reproduction (p. 204). He admits that the choice for the term neighbourhood carries the burden of co-opting a colloquial term for technical use, and that there is no ideal way to designate "localities" as actual social forms (pp. 222-223). I consider the term neighbourhood inadequate for the description of such large and dispersed groups as diaspora, and therefore will here prefer the term "community." So, locality refers to a property of social life and community to social forms in which locality is realised.

Locality, Appadurai claims, is a fragile social achievement. Even in the smallest, most isolated societies local subjects must be produced with the help of spatial symbolism, and locality must be maintained against various kinds of odds (ecology, other societies). Appadurai points out how the relationship between the production of local subjects and the communities in which such subjects can be produced, named and empowered to act socially is historical and dialectical. Furthermore, he stresses the importance of context and power in analysing the link between locality and community. To transform "spaces" into "places," is inherently an exercise of power (Appadurai 1995, 208-209). The capability of communities to produce local subjects is affected profoundly by the locality-producing capabilities of larger-scale social formations such as the nation-state. Appadurai notes a steady increase in the efforts of the modern nation-state to define all communities under the sign of its forms of allegiance and affiliation. However, he claims as well that this process of homogenisation is under threat from (1) the growing disjuncture between territory, subjectivity and collective social movement, and (2) the steady erosion of the relationship between spatial and virtual communities (p. 213). We will look into these processes here.

\section{Human Motion and Virtual Communities}

The creation of a "homogeneous space of nationness" by the nation-state is increasingly under threat from the forms of circulation of people characteristic of the contemporary world. Human motion has increased rapidly throughout the late twentieth century. The lure of economic opportunity drives people to migrate, as does the deprivation of human needs (droughts, famines, war, repression). Other forms of human movement are provided by the leisure industries, which create tourist sites and locations around the world, and the growing group of "cosmopolitans" and "expats" (United Nations personnel, technologists and specialists). According to Appadurai, these forms of circulation create complex conditions for the production and reproduction of locality. "The production of locality faces the twin problems of displaced and deterritorialised populations, and of state policies that disempower the capabilities both of communities to be context-producing and of local subjects to be anything other than national citizens" $(1995,217)$. The dark side of the "people" production needs of nation-states, particularly when directed at populations regarded as potentially subversive, is that it can create xenophobia, state paranoia, forced migration, and cycles of ethnic cleansing. Eastern Europe, and Bosnia-Herzegovina and Kosovo in particular, are perhaps the most tragic examples of such "state/refugee domino processes" (p. 216). In Western Europe, the policy of "multiculturalism" carries within it the paradox that it seeks to give room to (cultural) diversity strictly within the framework of, and defined by the nationstate. 
However, increasingly the intermediate surveillance of the nation-state is bypassed by new transnational forms of communication, such as fax machines, email and other forms of computer-mediated communication. Each of these developments, of course, interacts with the others, creating complicated new connections between producers, audiences and "publics," local and national, stable and diasporic (p. 218). These numerous new forms of communication affect the capability of communities to be context producing rather than largely context-driven (see for instance the use of the Internet: the "netwar" of the Zapatistas, and the Serbian anti-Milošević B92 internet-broadcasting from The Netherlands). Particularly the Internet allows debate, dialogue and relationship-building among various territorially divided individuals, who nevertheless are forming "communities of imagination and interest," the so-called virtual communities (p. 219). Appadurai warns not to oppose too strongly spatial communities to virtual communities since the relationship between the two is rather complex. Virtual communities are able to mobilise ideas, opinions, monies and social linkages which often directly flow back into lived communities, in the form of currency flows, arms for local nationalisms, and support for various positions in highly localised public spheres (p. 219). Furthermore, he uses the example of India to illustrate that these "new patriotisms" are not just the extensions of nationalist and counternationalist debates by other means, but are themselves changing in the light of new forms of electronic mediation.

(T)hough there is certainly a good deal of prosthetic nationalism and politics of nostalgia involved in the dealings of exiles with their erstwhile homelands, (t)hey also involve various puzzling new forms of linkage between diasporic nationalisms, delocalised political communications and revitalised political commitments at both end of the diasporic process (Appadurai 1995, 220, emphasis added).

Thanks to their active involvement in politics in their former homeland (on issues such as ethnic violence, party politics, domestic abuse), U.S. Indians are more inclined to participate in "minoritarian" politics in the U.S. itself. Appadurai concludes that the politics of diaspora have been decisively affected by global electronic transformations. Rather than a simple opposition between spatial and virtual communities, what has emerged is a significant new element in the production of locality. The global flow of images, news and opinion now provides part of the engaged cultural and political literacy that diasporic people bring to their spatial communities.

In sum, we view the production of locality as primarily a political struggle. Due to human motion and the emergence of virtual communities this political struggle is no longer territorially bounded. How can we now use these insights in our study of the role of diaspora communities in intra-state conflict? What follows from Appadurai's framework is that conflict should be understood as a struggle between the locality producing capabilities of two or more social formations. Generally, in this struggle the localising power of the nation-state is dominant and capable to define all other social formations (e.g. identity groups) under the sign of its forms. However, at times of conflict this dominance of the nation-state is contested. Identity groups, as Azar calls them, or "national minorities" (Danforth 1995) resist assimilation into the nation-state. In other cases, the nation-state has lost (or is un- 
able to produce) localising power (the so-called "weak" or "failed" states). Recent examples of this counter-nationalism or separatism include the break down of Yugoslavia, conflicts in Indonesia (Ambon, Atjeh), Northern Ireland, the Bask Country, and the Congo. "If national minorities choose to resist assimilation and retain, or more properly, construct, their own histories, cultures and identities, they must do so without the vast array of facilities that are available to the state, such as national universities, state primary schools, standardised print languages, and ceremonies of national independence" (Danforth 1995, 22). This was for instance the case in Kosovo, where Albanian Kosovars set up an underground parallel school system during the Milošević regime.

I am not totally convinced of the usefulness of the term locality. Sometimes I feel it creates more confusion than clarity. In addition, the above picture presents an a-political, a-historic view of the nation-state. Conversely, an important advantage of the idea of locality is that it offers room to study the construction of virtual communities and processes of delocalisation. If properly made operational, the term could help to analyse the struggle of ordinary people in intra-state and nationalist conflict and their efforts to "produce locality." Nationalism as seen not by governments and the spokesmen and activists of nationalist movements but by ordinary persons. Particularly in civil wars and intra-state conflict "ethnic marking" is very important. Protestant youths in Belfast painting the pavements of their neighbourhood during the Orange marches, saying this is my land, you don't belong here. Or the more subtle examples such as the stickers you'll find at practically every traffic light in Barcelona, saying: This is Not Spain. An important question with respect to the role of diaspora in intra-state conflict is therefore in what way they are able to strengthen their "homeland-groups" capabilities to be context producing.

\section{Nationalism and Counter-Nationalism}

Appadurai presents the nation-state as a rather static, a-historic, top-down entity that out of a sort of wilful cultural Machtsbedürfniss imposes homogeneity and "localises by fiat, by decree and sometimes by the overt use of force" $(1995,215)$. Others, like Gellner (1983) have a more historic view and see the nation-state and nationalism as rooted in a new division of labour that went with the process of industrialisation. It is not the case, Gellner claims, that nationalism imposed homogeneity; it was rather the objective need for homogeneity (inherent to the age of industrialisation) which was reflected in nationalism (Gellner 1983, 46). Industrialisation engendered a mobile and culturally homogeneous society, which differed importantly from the previous stable, stratified, and absolutist agrarian societies. "The fact that sub-units of society are no longer capable of self-reproduction, that centralised exo-education is the obligatory norm, that such education complements (though it does not wholly replace) localised acculturation, is of the very first importance for the political sociology of the modern world" (Gellner 1983, 34).

However, nationalism and nationalist struggles have played different roles in different era's and contexts (see Hobsbawm 1990). The liberal, "unifying nationalisms" of the 19th century Europe differ substantially from the separatist nationalisms of the late twentieth century. Contemporary nationalist struggles are largely counter-nationalistic: identity groups resist assimilation into the nation-state. In 
fact, every nationalist attempt to create a nation or a "people" at the same time creates national minorities, and potential new nationalisms. Gellner's remarkably simple and clear definition of nationalism is applicable to different kinds of nationalisms. "Nationalism is primarily a political principle, which holds that the political and the national unit should be congruent" (Gellner 1983, 1). Whereas Appadurai tends to phrase the process of nation building and nationalism primarily in terms of "locality production power," Gellner focuses on "culture:" "nationalism is a political principle which maintains that similarity of culture is the basic social bond" $(1995,3)$. The nation can be defined as a "shared culture." In his 1983 book on nationalism Gellner sketches a variety of ways in which the nationalist principle can be violated. The political boundary of a given state can fail to include all the members of the appropriate nation (e.g. Milošević's Serbia); or it can include them all but also include some foreigners; or it can fail in both these ways at once, not incorporating all the nationals and yet also including some non-nationals (as was the case in the entire Yugoslavia conflict). Or again, a nation may live, unmixed with foreigners, in a multiplicity of states, so that no single state can claim to be the national one (e.g. Kurdistan). Another violation of the nationalist principle, one that nationalist sentiment is particularly sensitive to, is the form in which the rulers of the political unit belong to a nation other than that of the majority of the ruled (e.g. Rwanda, Kosovo, Northern Ireland). Most contemporary violent conflicts seem to fit one or more of the above categories. Of course, "shared cultures" and ethnic or national identities are by no means static, or naturally given. Key questions underlying the study of nationalist conflicts are how and why groups of people consider themselves to be members of the same "culture," or are made to do so by others, and why they engage in a struggle for "their own" state. These processes of identification and ascription, and the transformation of these identifications into "imagined political communities" (Anderson 1983) are central to the study of nationalist conflict.

There is, however, an important shortcoming in theories on nationalism. Until recently, theories on nationalism all stressed the centrality of territory and boundaries: ethnic or national boundaries should not cut across political ones. "Let all nations have their own political roofs, and let all of them refrain from including non-nationals under it" as Gellner $(1983,1-2)$ put it. Taking this as point of departure, it is hard to assess the "long-distance nationalism" of diaspora communities and their involvement in nationalist conflicts in their erstwhile homelands, particularly when they have no serious intention of returning to their Heimat. Can we still speak of "nationalist" struggles when extremist live, work and operate in territories that are thousands of miles away from than the ones they are fighting for? Is "long-distance nationalism" not a contradictio in terminis?

No, I don't think so. Rather, nationalism has changed: the phenomenon has outgrown its definition. In contrast to the expectations of many, globalisation (including the internationalisation of labour, mass migration) has not meant the end of nationalism. Instead, nationalists (Catalans, Kosovar Albanians, Macedonians, Serbs) have begun to carry out their struggles on a global scale. National communities are being "imagined" in a new (delocalised) way. We are witnessing the construction of transnational national communities. (Danforth 1995, 80). People remain loyal to a national homeland they no longer inhabit. Of course, ethno-na- 
tionalist diaspora have existed in one form or another since ancient times. However, advances in communication and transportation have increased their size, visibility, and impact within the international system. Diasporas are able to remain much more deeply involved in the national struggles in their homelands than they ever could before. In addition, both multicultural policies and xenophobia in the Western countries enable and force newcomers to continue to define themselves in terms of their ethnic or national origin. Next, the declining importance of classbased political parties and movements went with the rise of "identity politics" (Anderson 1992). "Exile is the nursery of nationality," Lord Acton already stated in the 1860s (Lord Acton 1967, 146, cited in Anderson 1992, 1), and the contemporary long-distance nationalism nurtured there has become a significant force in today's global world (Danforth 1995, 81).

\section{The Delocalisation of Conflict Dynamics}

By long-distance interference with the conflict in their homeland, diaspora communities are engaged in a sort of "virtual conflict:" they live their conflicts through the internet, email, television, and telephone without direct (physical) suffering, risks, or accountability. Therefore they are engaged in processes of conflict dynamics that differ importantly from their identity group members in their homelands. Although hardly investigated, this "delocalisation" of contemporary conflict and the "long-distance participation" of diaspora communities are likely to have a complex, and crucial, effect on the conflict. Let us turn to conflict theory to further elaborate on this.

Contemporary conflicts are often about the role and status of identity groups within states. In broad terms, conflict can be defined as "the pursuit of incompatible goals by different groups" (Miall et al 1998, 19-20). These goals, however, are by no means static or fixed. Conflicts, and particularly the violent, civilian conflicts under study here, are dynamic processes with complex life cycles. In the late 1960s Galtung $(1969 ; 1996,72)$ introduced an influential model of conflict dynamics. He suggested that conflict should be seen as a triangle, with contradiction (C), attitude (A), and behaviour (B) at its vertices. Here the contradiction refers to the underlying conflict situation, which includes the actual or perceived "incompatibility of goals" between the conflict parties. Attitude includes the parties' perceptions and misperceptions of each other and of themselves. These can be positive or negative, but in violent conflicts parties tend to develop demeaning stereotypes of each other, and attitudes are often influenced by emotions such as fear, anger, bitterness and hatred. Attitude includes emotive (feeling), cognitive (belief) and conative (will) elements. Behaviour is the third element. It can include co-operation or coercion, gestures signifying conciliation or hostility. Violent conflict behaviour is characterised by threats, coercion and destructive attacks. According to Galtung all three components have to be present together in a full conflict. A conflict structure without conflictual attitudes or behaviour is a latent (or structural) conflict. Galtung sees conflict as a dynamic process in which structure, attitudes and behaviour are constantly changing and influencing one another. As a conflict emerges, it becomes a conflict formation as parties' interests come into conflict or the relationship they are in becomes oppressive. Conflict parties then organise around this structure to pursue their interests. They develop hostile attitudes and conflictual behaviour. 
And so the conflict formation starts to grow and develop. As it does so, it may widen, drawing in other issues and parties, deepen and spread, generating secondary conflicts within the main parties or among outsiders who get sucked in. Eventually, Galtung claims, resolving the conflict must involve a set of dynamic changes that involve a de-escalation of conflict behaviour, a change in attitudes, and transforming the relationships or clashing interests that are at the core of the conflict structure (Miall et al 1998, 14-15).

Since diaspora communities are physically separated from the "core conflict" they are engaged in different contradiction-attitude-behaviour dynamics. Even if the diaspora and the "homeland" communities have similar perceptions of the contradiction (C) (for instance, Serbian and Albanian Kosovar groups have incompatible goals because they both claim Kosovo/a to be "theirs"), they are likely to experience different emotions and develop different behaviour during the course of the conflict. Whereas the "homeland" groups that are physically engaged in the conflict will experience fear, hunger, pain, and stress, diaspora groups will probably feel anger, frustration or alienation. Consequently, these differences in attitudes will effect their behaviour and perception of the contradiction, and so forth.

The small number of scholars who have written about nationalist diaspora politics claim that diasporic and homeland groups live in different realities. Appadurai $(1990,11)$, for instance, stated that the homelands that lie at the symbolic centre of transnational national communities are "inventions;" they are products of the imagination of deterritorialised groups. Hence, diaspora and local groups may have different interests in maintaining the "homeland" as a collective identity and a source of cultural reproduction. Anderson, too, stresses that the political activities of the diasporic person are directed towards an "imagined Heimat" in which "he does not intend to live, where he pays no taxes, where he cannot be arrested, where he will not be brought before the courts, and where he does not vote: in effect, a politics without responsibility or accountability" $(1992,11)$. Although it is very likely that diaspora and local groups "imagine" their homeland differently (and therefore show different attitudes and behaviour) I would be more careful to oppose the two. Again, real life is more complex. Not all diaspora are engaged in just "virtual wars." For example, a substantial number of Kosovar Albanian in the diaspora returned to Kosovo in 1998 and 1999 to participate in the conflict. They crossed the border between virtual and real conflict. So far, there is very little case-material on the role of diaspora communities in intra-state conflict. What is becoming increasingly clear though is that it is no longer possible to understand ethno-nationalist conflict dynamics without incorporating the "diasporic" component.

\section{Conclusion}

There is reason to believe that the political weight of diaspora communities in intra state conflict has increased. This is related to the rise of new patterns of conflict, the speed of mobility and communication and the increased production of cultural and political boundaries in the Western countries. Group identities are much less territorially bounded. In order to analyse and understand these new phenomena this paper has looked at ideas on locality, nationalism and conflict dynamics. The focus on locality and "context producing capabilities" draws our attention to the rise of virtual communities and allows us to include everyday prac- 
tices into the analysis of diaspora and violent conflict. The focus on nationalism offers a more historical and political view on nation-building and minority nationalism and the construction of transnational national communities. Conflict theory, and particular conflict dynamics, helps to analyse the diasporic component in contemporary conflicts. Clearly, the above ideas and concepts need further elaboration and fine-tuning. This can only be done, however, with the help of solid empirical case studies. Hopefully, this paper has provided some useful directions for future research.

\section{References:}

Anderson, Benedict. 1983. Imagined Communities. London: Verso.

Anderson, Benedict. 1992. Long-Distance Nationalism: World Capitalism and the Rise of Identity Politics. The Wertheim Lecture 1992. Amsterdam: Centre for Asian Studies.

Appadurai, Arjun. 1990. Disjuncture and Difference in the Global Cultural Economy. Public Culture 2, 1-24

Appadurai, Arjun. 1995. The Production of Locality. In R. Fardon (ed.), Counterworks: Managing the Diversity of Knowledge, 204-225. London: Routledge.

Azar, Edward. 1990. The Management of Protracted Social Conflict: Theory and Cases. Dartmouth: Aldershot.

Basch, Linda, Nina Glick Schiller, and Cristina Szanton-Blanc. 1994. Nations Unbound: Transnational Projects and the Deterritorialized Nation-state. New York: Gordon and Breach.

Clifford, James.1994. Diasporas. Cultural Anthropology 9, 3, 302-338.

Danforth, Loring. 1995. The Macedonian Conflict: Ethnic Nationalism in a Transnational World. Princeton, NJ: Princeton University Press.

Galtung, Johan. 1969. Conflict as a Way of Life. In H. Freeman (ed.), Progress in Mental Health, 54-69. London: Churchill.

Galtung, Johan. 1996. Peace by Peaceful Means: Peace and Conflict, Development and Civilization. London: Sage.

Gellner, Ernest. 1983. Nations and Nationalism. Oxford: Blackwell Publishers.

Gellner, Ernest. 1995. Nationalism. London: Phoenix.

Hobsbawm, Eric. 1990. Nations and Nationalism since 1780. Programme, Myth, Reality. Cambridge: Cambridge University Press.

Holsti, Kalevi. 1996. The State, War, and the State of War. Cambridge: Cambridge University Press.

Kaldor, Mary. 1996. Cosmopolitanism versus Nationalism: the New Divide? In R. Caplan and J. Feffer (eds.), Europe's New Nationalism: States and Minorities in Conflict, 42-58. Oxford: Oxford University Press.

Kaldor, Mary and Basker Vashee, eds. 1997. New Wars: Restructuring the Global Military Sector. London: Pinter.

Koser, Khalid and Helma Lutz. 1998. The New Migration in Europe: Social Constructions and Social Realties. London: Macmillan.

Miall, Hugh, Oliver Ramsbotham, and Tom Woodhouse. 1998. Contemporary Conflict Resolution. Cambridge: Polity Press.

Safran, Wiliam. 1991. Diasporas in Modern Societies: Myths of Homeland and Return. Diaspora 1, 1, 83-99.

Tötölian, Khachig. 1991. The Nation State and its Others: In Lieu of a Preface. Diaspora 1, 1, 3-7.

Vertovec, Steven. 1999. Conceiving and Researching Transnationalism. Ethnic and Racial Studies $22,2,447-463$.

Wallensteen, Peter and Margareta Sollenberg. 1997. Armed Conflicts, Conflict Termination and Peace Agreements 1989-96. Journal of Peace Research 34, 3, 339-358. 